\title{
'A solemn judicial farce, the mere mockery of a trial': the acquittal of Lieutenant Lowe, 1827
}

\author{
Kelly K Chaves
}

On a morning in August 1826, at Wallis' Plains, in the district of Northumberland, 80 miles north of Port Jackson, three shots rang out in quick succession, followed closely by a fourth. ${ }^{1}$ When the smoke from the muskets cleared, one A boriginal man, slumped over from the weight of the chains that bound him to a gum tree, was dead. When one 'ball hit him in the back of the neck, the black turned round his head' and looked at his assailant. A nother soldier 'fired and the bullet cut along the jaw and broke the bone'. The third shot missed the prisoner. The Aboriginal man turned his head again and 'another Soldier stepped up, fired and blew his head to pieces'. ${ }^{2}$ The soldiers who fired the fatal shots, accompanied by their commanding officer, Lieutenant N athaniel Lowe, ${ }^{3}$ left the bloody body in the dust and returned to their barracks for breakfast. ${ }^{4}$

Later that evening, Lowe ordered his sergeant, Lewis Moore, to find two or three men to dig a grave. Sergeant Moore found William Constantine, who worked as a messenger in Wallis' Plains and asked him to assist in the burial. Constantine agreed, and found two more men, William Salisbury and Thomas N ewton, to aid him. The men dug a shallow grave near the remains of a disused latrine at Government House in Wallis' Plains. ${ }^{5}$ Afterward, the body of the A boriginal man, referred to as 'Jacky Jacky', was thrown in and quickly covered up. ${ }^{6}$

This article explores the political, colonial and social environment in the period leading up to the Supreme Court trial of Lieutenant Nathaniel Lowe for the murder of Jacky Jacky in 1827. Whites had been tried for the murder of A borigines prior to Lowe,

1. Wentworth 1824: 73. The quote in the title of the article is derived from Wentworth's defence of Lieutenant Lowe at his trial. See: R v. Lowe [1827] (Macquarie University Division of Law, March 2005 [cited November 2004]); available from http:/ / www.law.mq.edu.au/ scnsw/ Cases1827-28/ html/ r_v_lowe_1827.htm. Hereafter: R v. Lowe[1827].

2. Threlkeld to Moore, 6January 1827 in Gunson (ed) 1974: 95.

3. The spelling of Lowe's last name is not uniform. In the court register his last name is spelled as 'Lowe'. The A ustralian uses the spelling 'Lowe' and 'Low', while the spelling used by the magisterial enquiry was 'Low'. Lowe, himself, signed his name both 'Low' and 'Lowe'. For consistency in this article, he is referred to as 'Lowe'.

4. R v. Lowe [1827]. It should be noted that the course of events noted in the opening paragraphs were the witness al legations against Lieutenant Lowe and not indisputable fact.

5. Threlkeld to Moore, 6January 1827 in Gunson (ed) 1974: 95.

6. R v. Lowe [1827]. 
but, unlike other cases, Lowe and possibly the magistrates at Wallis' Plains tried in vain to cover up the murder of the A boriginal man. Chief Justice Francis Forbes, along with Governor Ralph Darling and the Executive Council, continued to investigate the matter until Lowe's indictment for the murder. This demand for justice for the dead indigene marked the disparity between the legal ideals of British officials and the actual treatment of Aborigines by settlers. While the legal powers in the colony began to view A borigines as provisional British subjects, colonists viewed the indigenes as a hapless race subject to no legal protection. $R \mathrm{v}$. Lowe helped to define the legal status of the A borigines and raised questions about the extent of British sovereignty over the territory of New South Wales.

\section{Sovereignty}

Sovereignty, understood to be 'the supreme political authority of an independent state', is a complex and debated legal concept. ${ }^{7}$ Scholars have identified two dimensions of sovereignty: internal and external sovereignty. External sovereignty projected to fellow nations the power of a specific sovereign country. International law was developed to regulate external sovereign relations between countries. Internal sovereignty dealt with the internal governing of the people of a specific sovereign country. ${ }^{8} \mathrm{~A}$ pplication of the sovereign's law to a specific Crown colony came under the provision of internal sovereignty. Along with external and internal sovereignty, declatory and actual sovereignty played a role in colonisation. Declatory sovereignty involved Europeans claiming portions of countries by extending inchoate title to lands through the reading of proclamations and the planting of flags. ${ }^{9}$ While declatory sovereignty created a European-recognised title to foreign 'uninhabited' land, actual sovereignty did not eventuate until the claiming power colonised the land and incorporated the Indigenous population into their legal system, usually by acknowledging the indigenes to be subjects of the sovereign, entitled to all the rights and benefits thereof. Declatory sovereignty, such as the reading of commissions and the planting of flags, did not ensure actual sovereignty. Actual sovereignty involved exercising power over the lives and fortunes of the Indigenous population and not the mere planting of flags.

In British colonial possessions, colonists brought the authority of the state to the settlement through their establishment of the Common Law in the new territory. ${ }^{10}$ Colonial courts, acting on instructions from the British Colonial Office, rapidly established the Crown's authority over British colonial residents. The presence of the colonists alone, however, did not extend British sovereignty over Indigenous populations.

Henry Reynolds approached the legal question of sovereignty in his 1996 book, A boriginal sovereignty: reflections on race, state and nation. He tried to pinpoint the moment at which Australia became subject to British sovereignty. ${ }^{11}$ While Reynolds expounded the historical dialogue of sovereignty, his book did not mention the Lowe

\footnotetext{
7. Garner 2000: 331.

8. Laski 1921: 27.

9. Laski 1921: 27.

10. Baker 1979: 11-13.

11. Reynolds 1996.
} 
case. Indeed, very few historians have written on the legal consequences and outcomes of this important case. The majority of these omissions can be forgiven, however. Since continuous law reporting did not begin in Australia until well after 1836, many early cases, such as Lowe's, remain relatively unknown. Fortunately, this has changed in recent years. After many years of research, Bruce Kercher, a pioneer in A ustralian legal history, began reconstructing the legal record of colonial New South Wales. He made hundreds of early colonial legal cases easily accessible to scholars on the World Wide Web, including that of Nathaniel Lowe. ${ }^{12}$

Although R v. Lowe can now be read in hypertext, very few legal scholars and legal historians mention this fascinating legal case in their discourse of sovereignty. Kercher believes that it was the first important case concerning issues of Indigenous sovereignty. ${ }^{13} \mathrm{McH}$ ugh refers to the case briefly in his recent book, A boriginal societies and the Common Law: a history of sovereignty, status and self-determination, but he draws few conclusions from it and merely recounts the outcome. ${ }^{14}$ Millis and Connor mention Lowe and his campaign in the Hunter Valley, but do not examine the legal aspects of the court case. ${ }^{15}$ This article, therefore, combines the legal-history approach taken by Kercher and McHugh (examining sovereignty) with the social history approach employed by Millis and Connor (examining social conditions) to investigate the social, cultural and political environment leading up to and surrounding the R v. Lowe case of 1827.

\section{The case in context}

The white population of New South Wales rose exponentially in the immediate decades after its founding: from the small contingent of 933 convicts and settlers in 1788, Sydney had expanded to a population of 23,939 convicts and settlers by $1820 .{ }^{16}$ Rapid population growth required an equally rapid accumulation and cultivation of land. Graziers raised much of the livestock in Australia for meat and for wool. Established settler Gregory Blaxland, who owned both cattle and sheep, echoed the opinion of many settlers in calling for a 'Chartered Stock Company' to set quality standards for wool production. Should such a company be formed, Blaxland believed that the company's sheep 'might be driven over an unlimited range so that they do not approach within five or ten miles of located [settled] land'. ${ }^{17}$ Blaxland's belief in an open grazing area for the sheep necessitated the acquisition of large tracts of territory outside Sydney. To reap a profit and maintain a heal thy stock, flocks and herds were kept 'moving ever onwards', expanding the bounds of the colony westwards and northwards. ${ }^{18}$ The European hunger for good grazing land for their sheep and cattle exposed more A boriginal clans to the culturally destructive influences of the Europeans.

The British, in their bid for expansion, did not conciliate Aboriginal aggression as they had in their North American colonies. The orders issued to the governor of New South Wales, Ralph Darling (1825-1831), stated:

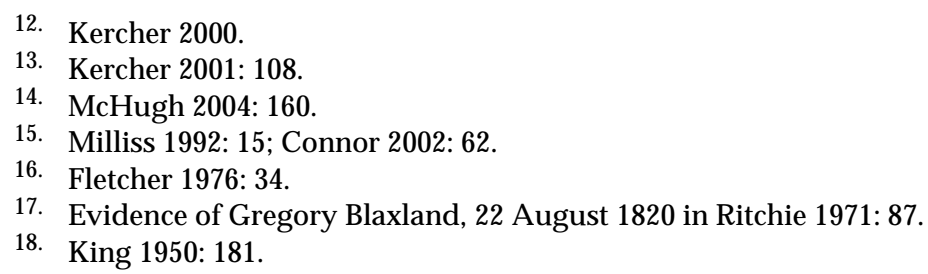


In reference to the discussions, which have recently taken place in the Colony respecting the manner, in which the Native Inhabitants are to be treated when making hostile incursions for the purpose of Plunder, you will understand it to be your duty, when such disturbances cannot be prevented or allayed by less vigorous measures, to oppose force by force, and to repel such Aggressions in the same manner, as if they proceeded from subjects of any accredited State. ${ }^{19}$

Henry Bathurst, third Earl Bathurst and Secretary of State for War and the Colonies 1812-1827, indicated that Darling needed to protect the lucrative wool industry, if necessary at the cost of amicable settler-Indigenous relations. There was a significant change, from Governor Arthur Phillip's policy of treating the Aborigines with 'amity and kindness' to Darling's political instructions to 'oppose force by force' if necessary. ${ }^{20}$

By 1825, A borigines had experienced 37 years of cultural contact with the British settlers. Legally, the British officials believed that the Aborigines, as non-Christian people, needed both Crown protection and civil indoctrination into Anglo-Saxon society. Technically, they believed that the liberty, and consequently the potential rights, of individual A borigines were the same as British subjects. ${ }^{21}$ Yet, the colonial government understood that this supposed legal equality required an anglicised Aborigine, one 'transformed by Christianity and education' and endowed with property-owning ideals. ${ }^{22}$

Governor Lachlan Macquarie (1810-1821) in 1814 attempted to exercise his role as guardian of the Indigenous people by opening a native institution for children. There, A borigines would be moulded into citizens 'in some degree useful to the community'. ${ }^{23}$ And Macquarie was not referring to bettering the Aboriginal community, but to enhancing the white colonial community. Two years later, in the midst of an A boriginal frontier uprising, Macquarie again tried to use his roleas Indigenous legal guardian. He proclaimed that 'such of the natives as may wish to be considered under the Protection of the British Government and disposed to conduct themselves in a peaceable inoffensive manner' would be issued government certificates to 'protect them from being injured or molested by any person' ${ }^{24} \mathrm{He}$ would then authorise government officials to assist them with 'cultivating their farms' by supplying them with 'wheat, maize and potatoes'. ${ }^{25}$ Macquarie, following British Indigenous policy, extended legal protection to A borigines who amalgamated into white society by choosing to become educated, God-fearing property owners. While the laws of the colony, supposedly, protected the Indigenous people, the reality varied extremely.

19. Bathurst to Darling, 14 July 1825 in Watson (ed) 1971, vol 12: 21.

20. Instructions to our trusty and well-beloved Arthur Phillip, Esq. in Bladen (ed) 1978, vol 1 part 2: 89. See also: Bathurst to Darling, 14July 1825 in Watson (ed) 1971, vol 12: 21. For a discussion on the A borigines being viewed as British subjects see, Atkinson 1997: 152-153, 158-167.

21. McHugh 2004: 131.

22. McHugh 2004: 131.

23. Black N atives Establishment of Institution of Children, 10 December 1814, N ew South Wales State Records [hereafter N SWSR], M iscellaneous Correspondence Relating to A borigines [hereafter MCRA], 5/ 1161: 17-18.

24. Proclamation Against the Natives, 4 May 1816, NSWSR, MCRA, 5/ 1161: 29.

25. Proclamation Against the Natives, 4 May 1816, NSWSR, MCRA, 5/ 1161: 32. 
Settlers' opinions differed from legal opinions in the colony. In 1825, James T Ryan, a free settler, wrote that the Aborigines 'are an indolent race of people, al ways dirty and filthy in their habits. Very few could be brought to a state of civilisation. ${ }^{26}$ William Charles Wentworth, an influential member of Sydney society, discussed the Aboriginal inhabitants of Australia in the third edition of his book, A statistical account of the British settlements in Australasia, only after first discussing poisonous snakes. When Wentworth did mention them, he stated that the Indigenous inhabitants of Australia 'occupy the lowest place in the gradatory scale of the human species'. ${ }^{27}$ Many other colonists echoed the sentiment that the Indigenous population could not be civilised and depended solely on the goodwill of Europeans for food and clothing. Some assumed that 'it is practicable to civilize them; but not to bring them to habits of industry'. 28

In 1813, the English expanded into the Hunter Valley, north of Sydney and in 1823, into the county of Argyle, southwest of Sydney (Fig 1). ${ }^{29}$ Settlers encountered Indigenous opposition to their outposts. On 1 May 1826 in the county of Argyle, Aborigines violently opposed the 'interference on the party of the stock keepers with the A boriginal females' ${ }^{30}$ A rgyle County had had little experience with Aboriginal retributive justice. Yet, according to the A ustralian newspaper, 1000 A borigines gathered near Lake Bathurst to retaliate against stock keepers who forced their affections on Indigenous women. Confronting a stockman residing at Mrs Sherwin's station, the Aborigines killed him and then continued onto a neighbouring station to 'very much ill treat the stockman there'. ${ }^{31}$ Four members of the army, residing in the county, followed thelarge band of indigenes and captured three. The government sent additional troops from Liverpool, in the County of Cumberland, to assist in the pacification of the region. ${ }^{32}$ The conflict in Argyle county created such public outrage that, on 5 May 1826, the colonial secretary issued a government notice concerning relations with the Indigenous peoples. Governor Darling expressed his concern that:

the proceedings of the natives are the effect of resentment at the outrages committed upon them by Stock keepers, who interfere with their women, and by such and other acts of aggression provoke them to retaliate. ${ }^{33}$

The stock keepers had been raping and stealing A boriginal women in the county of Argyle leading to hostility between the two racial groups. Station owners denied al legations that their stockmen raped the Indigenous women. Instead, they claimed that the 'first cause of ill blood originated in a communication between the Mudgee Blacks \& those on Hunters River'. The Mudgee people, they argued, perpetrated 'several acts

26. Ryan 1894: 107.

27. Wentworth 1824: 6 .

28. Evidence of Lieutenant A rchibald Bell, 27 N ovember 1819 in Ritchie (ed) 1971: 173.

29. Perry 1963: 61, 106.

30. Sydney Gazette and N ew South W ales A dvertiser, 10 May 1826.

31. The A ustralian, 6 May 1826.

32. The A ustralian, 6 May 1826.

33. Government Notice, Colonial Secretary's Office, 5 May 1826 in Watson (ed) 1971, vol 12: 178. TheSydney G azette and N ew South W ales A dvertiser printed this Government N otice onto broadsides for distribution to the farthest part the colony. See Sydney Gazette and N ew South Wales A dvertiser, 10 May 1826. 


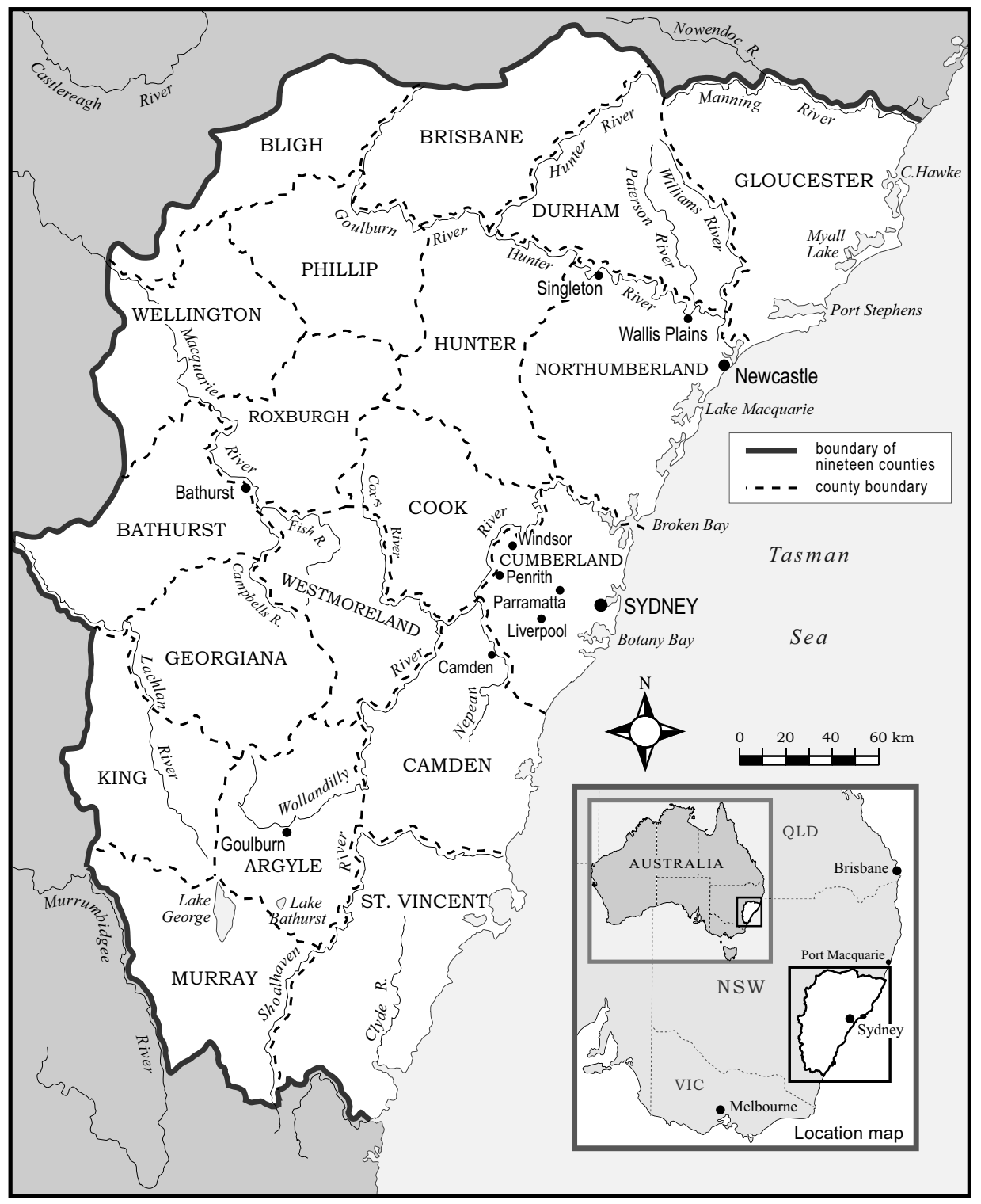

Fig 1. The counties of New South Wales

of aggression ... such as food and cloths being forcibly obtained from some of the lone Flock Stations'. ${ }^{34}$ Eyewitnesses, however, contradicted the squatters' denial of wifestealing and rape. Though stationed in the Hunter Valley, Lancelot Threlkeld, mission-

34. Report to the Governor on the Hostilities of the Black Natives, N ew South Wales State Records, MCRA, 5/ 1161: 42. 
ary to the Aborigines, personally beheld the violence used by the stockmen to carry away A boriginal women. One stockman 'was seen compelling a woman to accompany him by beating her with a stick'. ${ }^{35} \mathrm{~A}$ nother stockman beat 'a poor old man violently' for protecting his teenage daughter from being raped by the very stockman in question. ${ }^{36}$

Despite the unlawful conduct of the stockmen, Darling refused to condone the behaviour of the Indigenous population. While British law claimed to protect the individual rights of Indigenous people, it refused to acknowledge clan or tribal rights that dealt specifically with the 'governing and continuing authority of ... traditional polities and collective land ownership'. ${ }^{37}$ Darling, in dealing with the collective Mudgee clan, desired to show the Aborigines that they would 'not be allowed with impunity, in consequence of any supposed wrongs or injuries they may receive from Individuals to collect and disturb the country'. ${ }^{38}$ Darling sent a force of 32 men to apprehend the perpetrators and restore order to the region. The governor was prepared also to deal harshly with the stockmen, threatening, if they did not amend their ways, to withdraw 'permission to depasture the Lands beyond the boundaries of effective controul [sic] ... and these men [the stockmen] will be ordered into the Government Establishments'. 39 Darling's threat - to end land expansion and place the station workers back into government service - resonated with the landholders who feared losing their farms. For a time, they ordered their stockmen to control themselves. ${ }^{40}$

On 17 June 1826, however, the Australian reported that a group of Aborigines 'have become very troublesome in the district of Patrick's Plains' near the Hunter River. ${ }^{41}$ A borigines, believed to number 200, gathered at William Ogilvie's farm. Fearing trouble, Mrs Mary Ogilvie, in charge of the station in her husband's absence, talked to the indigenes and immediately disbursed maize and tobacco to them. Happy with the provisions, the A borigines left Ogilvie's property and moved on to Captain Robert Lethbridge's farm. Being refused provisions by Lethbridge's overseer and stockmen, the Indigenous party 'fell on the Overseer and Stockmen, killed and speared four Men $\ldots$ and plundered the People's Huts'. ${ }^{42}$

Acts of violence against people did not constitute the main worry for the wealthy landholders in the Hunter River region. The settlers of the region were often influential property holders and reported that the A borigines 'burnt all the grass on the several Farms, killed some Men, have speared several Cattle, and threatened to destroy the Wheat of the ensuing Harvest'. ${ }^{43}$ Though the landholders expressed more concern for their property than for their 'murdered' men, Governor Darling ordered a detachment of troops to punish the Indigenous inhabitants for their 'aggressions'. ${ }^{44}$ Like the attacks

\footnotetext{
35. Second Half Yearly Report of the A boriginal Mission Supported by the London Missionary Society, 21 June 1826 in Gunson (ed) 1974: 205.

36. Second Half Yearly Report of the A boriginal Mission Supported by the London Missionary Society, 21 June 1826 in Gunson (ed) 1974: 206.

37. McHugh 2004: 131.

38. Darling to Bathurst, 6 May 1826 in Watson (ed) 1971, vol 12: 269.

39. Government N otice, 5 May 1826 in Watson (ed) 1971, vol 12: 271.

40. Landholders to Darling, 4 September 1826 in Watson (ed) 1971, vol 12: 574.

41. The A ustralian, 17 June 1826.

42. Landholders to Darling, 4 September 1826 in Watson (ed) 1971, vol 12: 574.

43. Landholders to Darling, 4 September 1826 in Watson (ed) 1971, vol 12: 576.
} 
in the county of Argyle a few months previously, Darling blamed the stockmen of the Hunter Valley region for inciting the Aborigines to violence. ${ }^{45}$

Many settlers refused to blame the Indigenous attacks on the conduct of the stockmen. Settlers' attitudes towards the Aborigines left little room to give sympathy to 'savages'. The A ustralian, published by the lawyers William Charles Wentworth and Robert Wardell, revealed that, 'we have reason, however, to suspect that they [the attacks] did not originate in the misconduct of overseers or stockmen, but solely in the bad disposition of the Blacks'. ${ }^{46}$ Wentworth and Wardell disliked A borigines, and told the A ustralian's readers:

It is related of them [the A borigines] that they have acquired the notion that blankets, and etc have only been given to them by the Governor to ensure their good will and render them inoffensive, and that they have expressed their determination not to be bribed to preserve peace with the white people. ${ }^{47}$

The Aborigines living beyond Sydney refused to be bought with blankets and food. These actions confirmed settlers' opinions about the impossibility of temporising 'with savages, who have only cunning enough to comprehend that their enemies - enemies only in their own imagination - desire to conciliate them'. ${ }^{48}$ Many colonists believed the only civilising force the Indigenous people might acknowledge would be the 'cold steel' of a British bayonet. ${ }^{49}$

The settlers on the H unter River requested military support from the government. In response to their request, Governor Darling ordered the Mounted Police to the region. Governor Thomas Brisbane (1821-1825) had formed the Mounted Police in 1825. 'Members of the Mounted Police were soldiers, not civilian police' who volunteered for police duty. The men remained on the payroll of their regiment, but served with the police, patrolling the political borders of the colony. ${ }^{50}$ The recruits also received 'an extra sixpence or nine pence a day above their normal' pay according to their rank. The Mounted Police had a reputation for action; consequently, it was not hard to find volunteers for the plum posting of police work. ${ }^{51}$ Darling believed that the Mounted Police force would be adequate to quash the Indigenous uprisings, but Saxe Bannister, the Attorney-General of New South Wales and a friend to the Aborigines, disagreed: he demanded that the governor declare martial law and allow him permission to travel to the affected region. ${ }^{52}$ Darling scoffed at Bannister's suggestion and refused to declare martial law in the region. Bannister believed that the outrages in the Hunter River region necessitated martial law for the safety of the Aboriginal population, who would be 'best protected by the Government putting forth an overwhelming force'. ${ }^{53}$ Darling did not follow this advice; instead he ordered Lieutenant Nathaniel

44. Darling to Hay, 11 September 1826 in Watson (ed) 1971, vol 12: 574.

45. Darling to Hay, 11 September 1826 in Watson (ed) 1971, vol 12: 574.

46. The A ustralian, 7June 1826.

47. The A ustralian, 28June 1826.

48. The A ustralian, 28June 1826.

49. The Sydney M onitor, 2 June 1826.

50. Connor 2002: 62.

51. Milliss 1992: 15.

52. Darling to Hay, 11 September 1826 in Watson (ed) 1971, vol 12: 575.

53. Bannister to Darling, 5 September 1826 in Watson (ed) 1971, vol 12: 577. 
Lowe, of the 40th regiment, in command of a detachment of Mounted Police, to the region on 24June 1826.54

A few days after Lowe's arrival in Hunter Valley in 1826, 'the natives who lately committed such havoc among the stockmen ... retreated to the other side of the mountains'. ${ }^{55}$ The A borigines threatened to continue their raids on settlers when the weather warmed. Making arrangements for renewed attacks, troops were sent to support Lowe. The lieutenant, however, did not require their services. The killings began in July. An article expressing outrage in the A ustralian stated:

a report has reached town, of a native black having been fired at and killed, by a party of mounted police, on this side of the mountains. It is also said that the black in question had, himself, previously killed a stockman. ${ }^{56}$

A week later, another story surfaced of an A boriginal man shot by the Mounted Police without provocation. Subsequent killings occurred of Indigenous inhabitants by the Mounted Police that did not find their way into the Sydney papers. Messrs Scott and Macleod, magistrates of the Hunter River region, divulged that 'one of the Natives, who murdered Dr. Bowman's Watchmen ... was shot. Shortly after, several more Natives were taken by the Police, three of whom were shot. ${ }^{57}$ The death toll probably amounted to six Indigenous deaths, all while in custody. Roger Milliss asserted that Lowe 'soon distinguished himself by the vigour with which he threw himself into the job'. ${ }^{58}$ John Connor agreed, stating that Lowe carried out a 'campaign of terror in the upper Hunter'. 59

Government House in Sydney received word of the Indigenous killings in late August. On 11 August 1826, the Sydney M onitor printed a letter addressed to 'His Majesty's Attorney General \&C'. The letter, anonymously signed 'Trial By Jury', told the Attorney-General:

if you will enquire of the Constituted Authorities at N ewcastle, you will find the Black Native captured at that settlement, after being brought from the Interior fifty miles, was by British subjects, taken out and deliberately shot with a musket ball, of which he died. 60

Missionary Lancelot Threlkeld could have possibly written this message to the editor of the M onitor. For weeks, Threlkeld had been writing to his friends, including Saxe Bannister, trying to draw attention to the shooting of Jacky Jacky. In a letter to WA Hankey, Threlkeld acknowledged that he had sent word of the incident to the 'Attorney General and wait his answer'. Yet, Threlkeld begged Hankey not to publish 'this nor notice it except among the Directors [of the London M issionary Society]' due to public feeling in the colony. ${ }^{61}$

54. The A ustralian, 24June 1826.

55. The A ustralian, 28June 1826.

56. The A ustralian, 29June 1826.

57. Scott and Macleod to M cLeay, 3 October 1826 in Watson (ed) 1971 vol 12: 611.

58. Milliss 1992: 55.

59. Connor 2002: 64. For a legal interpretation of the case see: Kercher 2001.

60. The Sydney M onitor, 11 August 1826.

61. Threlkeld to Hankey, 1 August 1826 in Gunson (ed) 1974: 210. 
Pressured by public opinion, Darling recalled Lowe and then instigated an inquiry into the deaths. ${ }^{62}$ The three Indigenous dead were distinctive individuals, and while not as yet property-loving Christians, Darling still upheld the British legal ideal of protecting the rights of individual indigenes. ${ }^{63}$ Instructions to M essrs Close, Webber and Scott, the local magistrates of the region, revealed that they were to 'assemble and enquire into the circumstances of the killing of the Natives, alluded to, so that the Government may be enabled to determine whether it will be necessary to institute any proceedings in consequence'. ${ }^{64}$ Threlkeld placed little faith in these judicial proceedings. He believed that Lowe would be 'exonerated - as all the Magistrates here had previously signed a letter thanking him for his conduct in taking upon himself the responsibility of shooting his prisoner while in his safe custody'. ${ }^{65}$

Despite Threlkeld's prediction, Lowe and his men still needed to find explanations for three of the Aboriginal deaths in custody; the magistrates began to transcribe witness depositions that explained the Indigenous deaths in terms of military necessity for the preservation of civil order. Lowe had explicitly instructed his men to use force:

if ever they fell in with any of them [A borigines], who they knew to have committed any act of atrocity, that they must secure them, and if they attempted to escape by freeing themselves from the ropes, with which they were secured, to fire. ${ }^{66}$

One problem plagued the Mounted Policemen. They had not been in the region when the Indigenous attacks had occurred; therefore, they did not know who had participated in the violence and who had not. Lowe did not find this a problem. He personally promised his subordinates that if any of the suspected A borigines escaped, he would prosecute the Mounted Policeman who had allowed the indigene to flee successfully. ${ }^{67}$

Lowe terrified his men to such an extent that they followed his orders exactly and without question. Sergeant Lewis Moore, in his deposition taken 13 September 1826 by the magistrates at Glendon, complained that 'having Lieutenant Lowe's order to secure the Blacks when they were taken, he had nothing left for it but to order them to be shot' when three attempted to escape. ${ }^{68} \mathrm{He}$ confided to the Magistrates that he 'conceived he would be severely punished, if he had permitted the Blacks to escape'. ${ }^{69}$ Several men under Moore's command told the magistrates that the sergeant tried every possible

62. Darling had to contend with many influential members of society outraged at Lowe's behavior. The A ustralian covered the story of the probable killing of Jacky Jacky on 5 August 1826. The editors, Wardell and Wentworth, claimed to be 'rather anxious to know the particulars of this business'. While, in an earlier issue, theSydney M onitor, reporting on another Indigenous death at the hands of the M ounted Police, cried out for an enquiry so that, 'if true the perpetrators may be brought to justice, and the realm delivered from blood guiltiness!' See Sydney M onitor, 2 June 1826; The A ustralian, 5 August 1826; Darling to Bathurst, 6 October 1826 in Watson (ed) 1971, vol 12: 623.

63. McHugh 2004: 131.

64. McLeay to Allman, 28 August 1826 in Watson (ed) 1971, vol 12: 624.

65. Threlkeld to Burder and Hankey, 11 September 1826 in Gunson (ed) 1974: 214.

66. Examination of Lowe, 13 September 1826 in Watson (ed) 1971, vol 12: 626.

67. Examination of Lowe, 13 September 1826 in Watson (ed) 1971, vol 12: 626.

68. Examination of Moore, 13 September 1826 in Watson (ed) 1971, vol 12: 627.

69. Examination of Moore, 13 September 1826 in Watson (ed) 1971, vol 12: 627. 
avenue to recapture the A borigines before finally ordering them to be fired upon. The Indigenous men were, however, dead.

Lowe was removed from the Hunter River region, though not from all duties. Indeed, while Lowe was waiting to resume duty as an officer in the Mounted Police, Governor Darling appointed him a Justice of the Peace. ${ }^{70}$ Although Darling continued to trust the lieutenant, he decided, following a suggestion from Forbes, to send the acting Attorney-General, WH Moore, to the region. ${ }^{71}$ Moore was to investigate reports that an Aboriginal man had been deliberately shot by the Mounted Police. ${ }^{72}$ Forbes convinced Darling that the magisterial inquiry conducted months earlier had been inconclusive and that the Indigenous individual had a right to British justice. Moore arrived at Wallis' Plains on 18 January 1827.

In the early months of 1827 , Moore, as acting Attorney-General, received no cooperation from EC Close, the magistrate at Wallis' Plains, who believed himself, rather than Lieutenant Lowe, to be under examination. And the magistrate had good reason to suspect this. In orders issued to Close, Darling charged the magisterial body at Wallis' Plains with 'corruption or Neglect'. ${ }^{73}$ Moore assured Close that he 'knew of no such charge against him or any other Magistrate' and would 'confine my Inquiry to the objects I was directed to investigate'. ${ }^{74}$ In spite of these assurances, Close opted to ask the deponents at the second Magisterial Inquiry into the shooting of Jacky Jacky about his previous personal conduct. Not until the acting Attorney-General reminded Close that the inquiry dealt with the death of an Aboriginal man, did the subject turn away from the magistrate. ${ }^{75}$ Even with the focus on the shooting, Moore gained little information. Deponents changed their testimony from the previous inquiry, pretended to be unaware of the shooting, and denied knowing the names of the soldiers involved. One man suggested that any musket fire heard on the day in question arose from a few A borigines who were duck hunting for him. ${ }^{76}$ The unrevealing testimony continued. One witness, Ensign Archibald Robertson of the 57th Regiment, first admitted to hearing of 'a Black, who was implicated in the murder of Dr. Bowman's Shepherd, who was shot'. Later, however, Robertson corrected his testimony by stating that he did 'not know whose servant it was that was murdered'. The ensign al so refused to answer 'whether he had any conversation with Lieutenant Lowe respecting the shooting of a Black'. ${ }^{77}$ Moore remonstrated with the ensign and 'told him that it was a question that in any Court of Justice he would be bound to give an answer to'. Still, Robertson refused. Moore appealed to Close who decided that Robertson 'was not obliged to answer' the

70. List of Magistrates, 31 January 1827 in Watson (ed) 1971, vol 13: 59.

71. Attorney-General Saxe Bannister had resigned from office in October 1826 following a dispute over his salary with Governor Darling and the Colonial Office. The quarrels over salary aside, Darling and Bannister disagreed on many issues such as the A borigines, the convicts and the newspapers. See Fletcher 1984: 242-261.

72. Moore to Macleay, 22 January 1827 in Watson (ed) 1971, vol 13: 400. Appendices to Executive Council Minutes vol 1, Dec. 1825-1827, N SWSR, AO 4/ 1438: 232.

74. Moore to MacLeay, 22 Jan 1827, A ppendices to Executive Council Minutes vol 1, Dec. 18251827, N SWSR, AO 4/ 1438: 246.

75. Deposition of Reid and Robertson, 12 January 1827 in Watson (ed) 1971, vol 13: 408.

76. Depositions of Reid, Robertson, Boardman, Eckford, Hicks, Jones, and Duncan, 12 January 1827 in Watson (ed) 1971, vol 13: 408-410.

77. Deposition of Robertson, 12 January 1827 in Watson (ed) 1971, vol 13. 
question. ${ }^{78}$ Testimony continued in this vein. As the Criminal Sessions of the Supreme Court were at hand, Moore ran out of time and returned to Sydney without a satisfactory conclusion to the matter.

Moore left the region with one substantial lead. A man by the name of William Salisbury claimed to have been present when the shooting occurred, but he carried the stain of a convict and, worse, had re-offended and had been moved to a Sydney gaol. ${ }^{79}$ Police magistrates transcribed his deposition for Moore. Salisbury's statement confirmed that he and two other men assisted with the burial of Jacky Jacky's body. Unfortunately for the acting Attorney-General, Salisbury had been accused of perjury which 'greatly discredits his statement and if he has been convicted of the Perjury, he is rendered incapable of giving any testimony whatever'. ${ }^{80}$ Moore, however, found 'a man, who a short time before had been a constable' in Sydney who promised to help with the investigation. The unidentified 'man' returned two days later with information for Moore. A pparently, many people knew of the shooting, but 'there was a general fear in the neighbourhood of any one acknowledging what he knew' ${ }^{81}$

Someone had intimidated the witnesses. They refused to talk, they denied their past statements, and many moved away from Wallis' Plains, never to return. ${ }^{82}$ Even the newspapers, so vociferous on the subject of the Indigenous attacks and the proper way to handle the indigenes several months previously, remained silent about the inquiries and the alleged shooting. Nathaniel Lowe, though al ready proving himself capable of terrifying his men, could not al one have intimidated an entire region and silenced the newspapers. The conspiracy ran deeper. Most probably, given EC Close's unhel pful and suspicious conduct around Moore, the local magistrates helped to conceal the shooting, directly defying their legal responsibility to protect Indigenous individuals. Even after Lowe's trial for the shooting of the indigene was announced in the Sydney $M$ onitor newspaper, a 'correspondent at N ewcastle' wrote to the $M$ onitor claiming that there had never been a 'shooting of a black boy or Man at Hunter's River so often alluded to'. 83

Moore's 'man' provided him with another piece of evidence. He informed Moore that Thomas Farnham, late constable of Wall is' Plains, knew 'much more than he chose to say at the time he was examined on the first occasion'. ${ }^{84}$ Four months passed before Farnham could be located and questioned. On 26 A pril 1827, Farnham and Moore appeared before F Rossi, JP. Farnham stated that he had taken a handcuffed Jacky Jacky, who had allegedly killed a hut keeper at Dr Bowman's farm, to the military barracks. The Mounted Police chained the A boriginal prisoner to a fireplace and left him

78. Moore to MacLeay, 22 Jan 1827, A ppendices to Executive Council Minutes vol 1, Dec. 18251827, NSWSR, A O 4/ 1438: 248.

79. Moore to MacLeay, 15 January 1827, A ppendices to Executive Council Minutes vol 1, Dec. 1825-1827, NSWSR, AO 4/ 1438: 244.

80. Moore to MacLeay, 22 January 1827, A ppendices to Executive Council Minutes vol 1, Dec. 1825-1827, NSWSR, AO 4/ 1438: 252-253.

81. Moore to MacLeay, 22 January 1827 in Watson (ed) 1971, vol 13: 403.

82. Landholders to Darling, 4 September 1826 in Watson (ed) 1971, vol 13: 404.

83. Sydney M onitor, 11 May 1827.

84. Moore to MacLeay, 15 January 1827, A ppendices to Executive Council Minutes vol 1, Dec. 1825-1827, NSWSR, AO 4/ 1438: 253. 
handcuffed. Farnham claimed that a few members of the Mounted Police unchained Jacky Jacky from the fireplace and took him for a walk up a hill. After breakfast, the men and the prisoner had returned from their walk. Farnham collected his handcuffs and left Jacky Jacky very much alive. At that point in the questioning, Moore 'closely interrogated' the deponent, asking 'whether he had seen the said Jacky Jacky shot'. Farnham's resolve crumbled and he stated 'it was no use telling lies, that he had given his former Deposition under apprehension of dangers. That [he] would now disclose all Facts within his knowledge.' ${ }^{85}$ Farnham had returned from breakfast to find Lieutenant Lowe asking members of the Mounted Police to shoot the indigene. Lowe asserted 'at the time that as he [Jacky Jacky] had done the murder there was no harm in shooting a Cannibal like him'. ${ }^{86}$ Four soldiers, followed by Lowe, led the prisoner outside and chained him to a small sapling. Farnham had not heard Lowe order his men to shoot, though they had. After Jacky Jacky's murder, the constable left the region. Moore rushed this new damning eyewitness evidence to the Executive Council. ${ }^{87}$

Governor Darling conveyed the new testimony to the members of the Executive Council, who agreed that 'the whole case should be sent to the Acting Attorney General, with Instructions that he should he should resort to the proper measures that the Law might take its course in the ordinary manner'. ${ }^{88}$ The government charged Lowe with the murder of Jacky Jacky and brought him to trial in the Supreme Court. Before Saxe Bannister left the colony, he had contemplated trying Lowe for the murder of Jacky Jacky. Yet, Threlkeld, Bannister's close friend, counselled him against this course of action, proclaiming that it would only 'exasperate the Settlers more'. ${ }^{89}$ Bannister agreed with his friend and decided not to prosecute. The idea of a trial, however, nagged at Threlkeld. He believed that a 'party will bring him [Lowe] to trial as some wish to say it is the private intimation of the Governor that they [A borigines] should be shot and no further notice taken of it'. ${ }^{90}$ The missionary feared that a trial, and obvious acquittal, would only serve to reinforce the policy of wantonly shooting the Indigenous inhabitants to further expedite the seizure of Indigenous peoples' lands and disavow the noble doctrine of British protection for A boriginal inhabitants.

Forbes and Stephen heard the case of R v. Lowe on 18 May 1827. Lowe engaged William Charles Wentworth and Robert Wardell, the proprietors of the A ustralian and two of the best defence barristers in the colony, to defend him. Moore, still acting Attorney-General, prosecuted. Before the trial proper began, Wardell challenged the jurisdiction of the Court in trying the lieutenant for the murder of the Indigenous man, because, he argued, 'this Court has not jurisdiction to try a British subject for an alleged

85. Deposition of Thomas Farnham, 26 A pril 1827, A ppendices to Executive Council Minutes vol 1, Dec. 1825-1827, NSWSR, AO 4/ 1438: 261.

86. Deposition of Thomas Farnham, 26 A pril 1827, A ppendices to Executive Council Minutes vol 1, Dec. 1825-1827, NSWSR, AO 4/ 1438: 261.

87. Deposition of Thomas Farnham, 26 A pril 1827, A ppendices to Executive Council Minutes vol 1, Dec. 1825-1827, N SWSR, AO 4/ 1438: 262.

88. Minute N o. 33, 26 A pril 1827, A ppendices to Executive Council Minutes vol 1, Dec. 18251827, NSWSR, AO 4/ 1438: 91.

89. Threlkeld to Burder and Hankey, 4 September 1826 in Gunson (ed) 1974: 204.

90. Threlkeld to Burder and Hankey, 4 September 1826 in Gunson (ed) 1974: 204. 
offence, committed against that A boriginal native'. Wardell stated that the A borigines were not subjects

of the British King, because his [the Aborigine's] tribe has not been reduced under his Majesty's subjection, and because there has been no treaty, either expressed or understood, between his country and that of the British King. ${ }^{91}$

Even if the aborigines were subjects of the King, it would beimpossible to try them in a court of law because, under the $\mathrm{N}$ ew South $\mathrm{W}$ ales $\mathrm{Act}$, a jury was to be composed of seven military and naval officers. For an A boriginal subject to have a fair trial, according to the Laws of England, the jury would have to be composed 'half of British subjects and half of natives'. ${ }^{92}$ Wardell challenged the largely unwritten and essentially unproven doctrine of legal protection for Indigenous individuals.

Wardell argued that, if an A boriginal murderer could not be tried by the English court system, the question was how he could be punished to prevent offending divine law. The answer was that the defendant, Lieutenant Nathaniel Lowe, had enacted divine justice by killing the Aboriginal man in just retribution. Wardell summed up his argument by stating:

I have taken for granted that the crime of murder was committed by the native, and that having fallen into the avenging hand of the defendant, the latter becomes the instrument of divine vengeance, substitute for a court of Judicature, to prevent the offender's escape, and held up an example to his tribe, that they shall not commit murder with impunity. Punishment and example being the objects aimed at, it matters not whether the offending native was deprived of his life in the heat of a conflict or deliberately. ${ }^{93}$

Wardell then handed over to Wentworth to pursue a similar line of reasoning with the bench. Wentworth quoted Vattel, to the effect that 'when many independent families (and the natives of this colony are such) are established in a country, they occupy the soil and demesne of the country, but have no empire among them' ${ }^{94} \mathrm{He}$ believed that this, al ong with other principles of international law, proved that:

we could not, according to any principles, have assumed sovereignty over them; they are the free occupants of the demesne or soil, it belongs to them by law of nations, anterior to any laws which follow from human institutions, and that right is not at all attempted to be infringed upon by this Act of Parliament. ${ }^{95}$

Wentworth and Wardell requested that the charges against their client be dismissed.

This defence argument challenged British sovereignty, not merely over Aborigines living in rural areas such as Wallis' Plains, but throughout the expanding colony. The British had informally acknowledged that A borigines in close proximity to settlements were held to be under British law (to be protected from settlers or to be punished for transgressions). ${ }^{96}$ Yet, as Wardell and Wentworth argued, this implied metamorphosis of Indigenous man into British subject did not constitute a claim to

91. R v. Lowe [1827].

92. R v. Lowe [1827].

93. R v. Lowe [1827].

94. R v. Lowe [1827].

95. R v. Lowe [1827]. 
'thoroughgoing jurisdiction over them all'. ${ }^{97}$ Indeed, they argued that the extension of any form of sovereignty over the Indigenous inhabitants of the soil, by law, custom or practice, was illegal. In effect, they argued that the 24,000 or so English convicts and settlers unlawfully occupied Australian territory. It was impractical for tens of thousands of peopleto return to an overcrowded Britain; yet the government needed to recognise that the A borigines retained their own sovereignty and their own laws.

Had the Chief Justice accepted Wentworth and Wardell's jurisdictional plea, it would have amounted to judicial recognition of A boriginal sovereignty. He did not. Instead, Forbes ruled that:

if the Act of Parliament [N ew South Wales Act, 1823] has recognized a sovereignty over this country, and recognized the application of English law here, we must look to the British law as established here de facto.... I do not see any grounds to prove the want of jurisdiction of this Court, so as to call on me to stop the case. ${ }^{98}$

According to the Chief Justice, it was not the court's place to determine whether the occupation and the sovereign hold over the continent by the British was legal. The $\mathrm{N}$ ew South W ales A ct of 1823, written in part by Forbes, stated the jurisdictional and sovereign bounds of the Common Law in New South Wales and Van Diemen's Land (Tasmania). And Forbes was not about to overturn the Parliamentary legislation he had helped to draft..$^{99}$ The court, therefore, had jurisdiction over Lowe and he would have to face his trial. Justice Stephen concurred, stating further that the 'natives of this colony were within the protection of thelaws', and the trial must continue. ${ }^{100}$

Forbes and Stephen expressed current protection doctrine (protecting individual indigenes) in their rejection of Wentworth and Wardell's pre-trial demurrer. Forbes, in a two-tiered argument, acknowledged that Parliament, in the $\mathrm{N}$ ew South Wales Act of 1823, established sovereignty over the country. The second part of the Chief Justice's denial centered on the legal status of the A boriginal victim. Forbes claimed that the

native must be considered, whatever be his denomination, a British subject. If not to be an alien friend, or an alien ami, in any case he is entitled to lex loci, and it is only under peculiar circumstances he can be excluded from that right. 101

Stephen concurred. He clearly affirmed that the 'natives of this colony were within the protection of the laws'. ${ }^{102}$ The court aimed to protect the individual rights of the dead indigene, thus asserting overt sovereignty over Jacky Jacky and the rest of Indigenous population of Australia.

96. Depredations of the Blacks, 22 February 1797, NSWSR, MCRA 5/ 1161: 4. In the 1797 government notice, the government specified that settlers could band together to protect their property from the A borigines. Yet, they were not to 'wantonly fire at or take the lives of any of the Natives, as such an Act would be considered a deliberate Murder, and subject the offender to such punishment as (if proved) the law might direct to be implemented'. This notice acknowledged that $A$ borigines could be punished for transgressions, yet the whites could beheld accountable for any unnecessary violence.

97. McHugh 2004: 160.

98. R v. Lowe [1827].

99. 4 Geo. IV c. 96 in New South Wales Law Reform Commission 1973: 4-16.

100. R v. Lowe [1827].

101. $R$ v. Lowe [1827].

102. $R$ v. Lowe [1827]. 
Lowe pleaded not guilty to the murder charge, and the Crown called its first witness. Thomas Farnham testified that he heard Lowe order the killing of the Indigenous man and saw the execution. N ext, William Salisbury took the stand. Salisbury remembered seeing two soldiers and Lieutenant Lowe escort a black man behind Government House in Wallis' Plains the previous A ugust. He heard the report of three muskets, followed closely by a fourth. Later in the day, a 'laborer named N ewton' ordered two men to help dig a grave for the dead indigene. Salisbury participated in digging the grave and claimed that the dead man 'was wounded in the cheek and through the head; he had been bleeding a good deal'. ${ }^{103}$ Finally, acting Attorney-General Moore called William Constantine. Constantine had seen Sergeant Moore and Lieutenant Lowe arguing over what was to be done to the Aboriginal man, but did not hear the conversation. He did not see the murder, but, later in the day, Moore asked him to help bury the black man. Constantine consented to Moore's request and buried the body.

Wardell and Wentworth tried to discredit the damning eyewitness testimony for the prosecution by attacking the character of the witnesses. All three men who testified had been convicted of theft or robbery and transported to New South Wales; with the stain of convictism upon them, they had been sent to Wallis' Plains. Before the defence called witnesses, Wardell again asked the court to declare a mis-trial for lack of evidence. He believed that 'all the witnesses who had been examined, acknowledge themselves to be accomplices; their testimony was unsupported by any other evidence whatever'. ${ }^{104}$ Forbes denied the motion. Wentworth and Wardell called men to destroy the character of the prosecution witnesses further. They made no attempt to refute the witnesses' statements. Without Lowe taking the stand to explain what truly happened that day in August 1826, the defence rested.

Forbes summed up the case for the jury. He proposed to 'assume a general proposition - in all cases that the natives of this country (while they treat this soil) are entitled to the protection of our laws'. ${ }^{105}$ With that statement, the Chief Justice effectively expanded British sovereign control over the Indigenous population of Australia. Forbes clearly stated that British law applied to all the aborigines in the country.

Following this summing-up, the jury, composed of seven military men, retired. Five minutes later, they returned and the 'Foreman delivered a verdict - NOT GUILTY'. The courtroom broke out in general cheers and applause. Lowe's various friends congratulated him. When the lieutenant left the court, the public burst into applause. $^{106}$

Officials in N ew South Wales were not the only ones concerned with the outcome of Lowe's trial. One year after the lieutenant's acquittal, Darling forwarded a letter from the Duke of Wellington to Forbes. Wellington believed it 'desirablethat I should be able to report to $\mathrm{H}$ is M ajesty the exact state of the case regarding Lieut. Lowe's conduct'. ${ }^{107}$ The Duke requested a transcript of the trial from the Chief Justice. Forbes complied and

\footnotetext{
103. R v. Lowe [1827].

104. $R$ v. Lowe [1827].

105. R v. Lowe [1827].

106. $R$ v. Lowe [1827].

107. Wellington to Darling, 18 October 1827, Chief Justice's Letterbook, 1828-1835, N SWSR, 4/ 6651: 158.
} 
sent the results of the trial to Wellington in London. ${ }^{108}$ If any impropriety had occurred, the Duke wanted to make sure that he could explain it to King George IV.

Lowe's acquittal presented an interesting problem for the courts. Forbes and Dowling had upheld the idea of individual protection rights for Indigenous people, but the acquittal of Lowe discounted that protection. British law extended its sovereignty to all of the Indigenous population by allowing Lowe to be tried in a British court for the murder of an indigene. The courts gave protection to the A borigines with one hand and removed Indigenous legal autonomy with the other. Unfortunately for Jacky Jacky, Lowe's trial proved to be merely a 'solemn judicial farce'. ${ }^{109}$

\section{Acknowledgements}

I would like to acknowledge and thank the efforts of the readers for their help in shaping the final article. I would also like to thank my colleague, Dr Rick Clapton, for his editorial skill. Thanks also to Associate Professor David Philips for his useful suggestions and comments.

\section{References}

\section{Primary sources}

Black Natives Establishment of Institution of Children, 10 December 1814, N ew South Wales State Records [hereafter N SWSR], Miscellaneous Correspondence Relating to A borigines [hereafter MCRA ], 5/ 1161: 17-18.

Deposition of Thomas Farnham, 26 A pril 1827, A ppendices to Executive Council Minutes vol 1, Dec. 1825-1827, NSWSR, AO 4/ 1438: 262.

Depredations of the Blacks, 22 February 1797, NSWSR, MCRA 5/ 1161: 4.

Forbes to Darling, 21 May 1828, Chi ef Justice's Letterbook, 1828-1835, NSWSR, 4/ 6651: 159.

Minute No. 33, 26 A pril 1827, A ppendices to Executive Council Minutes vol 1, Dec. 1825-1827, NSWSR, AO 4/ 1438: 91.

Moore to MacLeay, 15 January 1827, A ppendices to Executive Council Minutes vol 1, Dec. 1825-1827, NSWSR, AO 4/ 1438: 253.

Proclamation Against the Natives, 4 May 1816, NSWSR, MCRA, 5/ 1161: 29.

Report to the Governor on the Hostilities of the Black Natives, NSWSR, MCRA, 5/ 1161: 42.

Wellington to Darling, 18 October 1827, Chief Justice's Letterbook, 1828-1835, NSWSR, 4/ 6651: 158.

108. Forbes to Darling, 21 May 1828, Chief Justice's Letterbook, 1828-1835, NSWSR, 4/ 6651: 159.

109. R v. Lowe [1827]. The legal rulings on A boriginal sovereignty did not end with R v. Lowe, 1827. Chief Justice Forbes and Justice Dowling heard two other important legal cases concerning A boriginal sovereignty: R v. Ballard, 1829 and R v. M urrell, 1836. Both Ballard and M urrell dealt with whether the court could punish an Aboriginal man for killing a fellow Aboriginal man. For a complete legal and social discussion of Ballard and M urrell, see Chaves 2005: 99-140. 


\section{Newspapers}

The A ustralian

Sydney Gazette and N ew South W ales A dvertiser

Sydney M onitor

\section{Secondary sources}

Atkinson, Alan 1997, The Europeans in A ustralia, Oxford University Press, Melbourne.

Baker, JH 1979, A n introduction to English legal history, Butterworths, London.

Bladen, FM (ed) 1978, H istorical Records of N ew South W ales, Lansdown Slattery, Mona Vale, New South Wales.

Chaves, Kelly K 2005, “'A very unfortunate circumstance”: the colonial evolution of defining British Sovereignty emanating from murder cases in New South Wales, 1790-1836', MA Thesis, University of Melbourne.

Connor, John 2002, The A ustralian frontier wars, 1788-1838, University of New South Wales Press, Sydney.

Fletcher, Brian H 1976, Colonial A ustralia before 1850, Thomas N elson Ltd, Melbourne.

— 1984, Ralph D arling: a Governor M aligned, Oxford University Press, Melbourne.

Garner, Bryan A (ed) 2000, Black's law dictionary, 7th abridged edition, West Publishers Co, St Paul, Minnesota.

Gunson, Niel (ed) 1974, A ustralian reminiscences \& papers of L.E. Threlkeld: missionary to the A borigines 1824-1859, A ustralian Institute of A boriginal Studies, Canberra.

Kercher, Bruce 2000 'Where the future meets the past: pre-1900 N.S.W. Case Law on the Web', U TS Law Review 2.

— 2001, 'The recognition of A boriginal status and laws in the Supreme Court of New South Wales under Forbes C.J., 1824-1836' in Land and freedom: law, property rights and the British diaspora, AR Buck, John M CLaren and Nancy Wright (eds), A shgate, Dartmouth.

King, CJ 1950, The first fifty years of agriculture in N ew South W ales, Government Printer, Sydney.

Laski, Harold 1921, F oundations of sovereignty and other essays, Harcourt, Brace \& Co, Freeport, NY.

McHugh, Paul G 2004, A boriginal societies and the Common Law: a history of sovereignty, status, and self-determination, Oxford University Press, Oxford.

Milliss, Roger 1992, W aterloo Creek: the A ustralia D ay massacre of 1838, G eorge Gipps, and the British conquest of $\mathrm{N}$ ew South W ales, McPhee Gribble, Ringwood.

New South Wales Law Reform Commission 1973, Imperial Acts and documents relating to N ew South Wales, Law Reform Commission of NSW, Sydney.

Perry, TM 1963, A ustralia's first frontier: the spread of settlement in N ew South W ales 17881829, Melbourne University Press, Melbourne.

R v. Lowe [1827] (Macquarie University Division of Law, March 2005 [cited November 2004]); available from http:/ / www.law.mq.edu.au/ scnsw/ Cases1827-28/ html/ r_v_lowe_1827.htm 
Reynolds, Henry 1996 A boriginal sovereignty: reflections on race, state and nation, Allen \& Unwin, St Leonards.

Ritchie, John (ed) 1971, The evidence to the Bigge R eports: N ew South W ales under Governor M acquarie, William Heinemann Australia Pty Ltd, Melbourne.

Ryan, James T 1894, Reminiscences of A ustralia, Nepean Family History Society, Sydney.

Watson, Frederick (ed) 1971, H istorical Records of A ustralia, WG Murray Government Printer, Canberra.

Wentworth, WC 1824, A statistical account of the British settlements in A ustralasia: including the Colonies of $\mathrm{N}$ ew South $\mathrm{W}$ ales and $\mathrm{V}$ an $\mathrm{D}$ iemen ' $\mathrm{S} L$ and: with an en umeration of the advantages which they offer to emigrants, as well with reference to each other, as to the $U$ nited States of A merica and the Canadas: and directions and advice to emigrants, Geo. B Whittaker, London. 